\title{
Locomotion Study of Bekantan (Nasalis larvatus)
}

\author{
Arvendi Rachma Jadi ${ }^{1}$, Amelia Rezeki $^{2}$, Ariana ${ }^{1}$, Dwi Liliek Kusindarta ${ }^{1}$, Hery Wijayanto ${ }^{1 *}$ \\ ${ }^{1}$ Department of Anatomy, Faculty of Veterinary Medicine, Universitas Gadjah Mada, Yogy akarta, Indonesia \\ ${ }^{2}$ Sahabat Bekantan Indonesia, South of Kalimantan, Indonesia
}

\begin{abstract}
The locomotion system in the primate is developed and diverged following the pressure of the environment. To survive, each species of primate will push their locomotor's evolution to accommodate their foraging activities. Generally, the primate locomotion system is classified into vertical clinging and leaping (such as Tarsius), quadrupedalism (such as guenon), brachiation (such as gibbon), and bipedalism (human). Classification is usually based on the intermembral index, the ratio between the arm and leg length in percentage. The intermembral index of bekantan is about 90 on average; means the arm length is $90 \%$ of leg length. Based on the intermembral index, bekantan's locomotion system is hindlimb dominated gait and supposed to be quadrupedal terrestrial. However, in their natural habitat, bekantan spend their daily activities mostly on the trees. Terrestrial and arboreal movements were observed during foraging. Arboreal movements of bekantan are dominant where the forest canopy is remaining good. On the other hand, in open areas and where they have adapted to human existence, quadrupedal terrestrial behaviors will be dominant during foraging. Further observation in various areas is still needed to strengthen the type of locomotion system of bekantan.
\end{abstract}

\section{Introduction}

Bekantan (Nasalis larvatus) is a unique non-human primate species found in Kalimantan, characterized by a big nose in the adult [1]. Such species are showing most sexual dimorphism. The male bekantan is much bigger (more than $20 \mathrm{~kg}$ ) with a big nose, while the female is smaller (less than $15 \mathrm{~kg}$ ) with a much smaller nose [2]. This species is found in one male with multi-female groups, which females can transfer to among the groups (each group sized in a vary of three to 32 members) $[3,4,5]$. Their societies are female-centered, whereas the males remaining aloof in most social interactions [2].

Bekantan is life in the varied habitat in Kalimantan, Sabah, Sarawak, and Brunei. They have been living in groups and usually close to the river, swamp, or beach which provided a big proportion of food, such as fruits and leaves $[2,6]$. They frequently have seen in the mangrove forest and familiar with the villagers [7].

Bekantan has large and strong hands and feet, which is crucial for them to well-swim, a tremendous capability for tidal and riverine habitats [2]. Its enlarged nose of bekantan is used for breathing while they are swimming, as well as for sexual distinction and amplify natural vocalization [8], which the female a little softer than the male's [2].

Movements of bekantan in Borneo are interested to observe, particularly in South Kalimantan. They move arboreally in the forest canopy by leaping quadrupedally walk from one tree to another tree, and forage in the ground as well. The locomotor system of mammalian will develop under environment pressure and is one of the body parts, which very important for survival things. Hunting prey or run from the predator is depending on the animal's ability to move using their locomotor system. Here, we report an anatomical background to relate to those movements.

\section{Materials and Methods}

\subsection{Materials}

Nine bekantans used as the anatomical samples were kindly provided by Sahabat Bekantan Indonesia, one of NGO works for bekantan conservation at South Kalimantan. From nine bekantans, we did anatomic measurements from three of them that have a good cooperation for measurement without anesthesia. We could not push ourselves to anesthetize other bekantan since they are very sensitive to anesthetics and very risky for such Appendix 1 animals. Vernier caliper was used to measure the length of bones in cranial and caudal extremities of bekantan.

\subsection{Methods}

Measurements are taken and indices used for this study for the length of the cranial and caudal extremities [9] : Humeral length : The maximum length of the humerus from the head to the capitulum

Ulnar length : The maximum length of the ulna (superior surface of the olecranon to the end of the styloid process)

Femoral length : The maximum length of the femur (the articular surfaces at the two end)

Tibia length : The maximum length of the tibia (the distance between the articular surface of the head and end of the medial malleolus)

*Corresponding author: herykh@ugm.ac.id 
In general, with the assumption that bekantan's anatomic variation only occurs one from one hundred individuals, a simple analysis was conducted to find out

$$
\frac{\text { Length Humerus + Ulna }}{\text { Length Femur + Tibia }} \times 100
$$

Three times of measurements were conducted by different researchers in both extremities left and right for forelimbs and hind limbs of bekantan.

\section{Results and Discussion}

Animal limbs are evolved depend on their behavior and habitat $[12,13,14]$.

Table 1. The length of forelimbs and hindlimbs of bekantan and intermembral index.

\begin{tabular}{llccc}
\hline Name & & $\begin{array}{c}\text { Ext. } \\
\text { Cranial }\end{array}$ & $\begin{array}{c}\text { Ext. } \\
\text { Caudal }\end{array}$ & $\begin{array}{c}\text { Intermembral } \\
\text { index }\end{array}$ \\
\hline Shiro & Right & 442.29 & 479.24 & 92 \\
& & 442.53 & 481.05 & 92 \\
& & 443.30 & 479.19 & 93 \\
& \multirow{2}{*}{ Left } & 442.06 & 480.52 & 92 \\
& & 440.98 & 479.37 & 92 \\
Mimin & \multirow{4}{*}{ Right } & 442.53 & 479.29 & 92 \\
& & 556.06 & 633.80 & 88 \\
& & 556.41 & 632.85 & 88 \\
& Left & 538.26 & 632.68 & 88 \\
& & 538.03 & 616.46 & 87 \\
Pedro & & 539.34 & 615.85 & 87 \\
& Right & 624.83 & 752.45 & 83 \\
& & 624.11 & 752.44 & 83 \\
& & 623.45 & 752.40 & 83 \\
& Left & 624.67 & 736.13 & 85 \\
& & 624.50 & 735.80 & 85 \\
& & 624.39 & 735.71 & 85 \\
& Average & & & 88 \\
\hline
\end{tabular}

Based on Table 1, bekantan has an intermembral index less than $100( \pm 90)$, which means that their hindlimb is longer than their forelimb. Intermembral index is determined by the length of (humerus + radius) $\mathrm{X} 100 /$ length femur + tibia [10,11]. Based on the intermembral index, the non-human primate is divided into three groups, namely; low $(50-80)$, moderate $(80-$ $100)$, and high index $(100-150)$ [13].

Bekantan's shoulder morphology seems to accommodate extended arm movements at the shoulder level, which means forelimb dominated positional activities such as arm swing, brachiation, and vertical climb [2]. Each non-human primate usually can move with some types of movement. The great apes walk quadrupedally by knuckle-walking, but they still capable their intermembral index. It was determined with $[10,11]$ :

to do brachiation on the trees. However, their heavy bodyweight pushing them to stay and foraging in the middle and lower forest canopy or the ground, except during nesting at night. Unlike the lower class of animals, non-human primates walk on the flats of their feet (plantigrade) since they have advance anatomy development $[2,9]$.

\section{Conclusion}

In conclusion, the intermembral index found from our measurement is \pm 90 . From the results, it is clear to decide that bekantan moves with its hind limb dominantly. All in all, the hind limb made the animals move forward when they walk quadrupedally or leaping, whereas bekantan rarely to walk bipedally.

The author would like to thank Sahabat Bekantan Indonesia (SBI) Foundation, Department of Biology, Lambung Mangkurat University, Natural Resources Conversation Centre (BKSDA) Banjarmasin, South Kalimantan for implementation of research collaboration and Faculty Veterinary Medicine Universitas Gadjah Mada for fully funding this research.

\section{References}

1. H Koda, M. Tadahiro, T. Augustine, G. Benoit, K.S.S.N. Senthilvel, J.S. Danica, A.R.R. Diana, C.M.S. John, O. Ismon, S. Rosa, S. Satoru, M. Ikki, Science Advances, 4, (2018)

2. L.E. Harding. Mammalian Species, 47, 84-99, (2015)

3. C.P. Yeager. American Journal of Primatology, 20, 95106, (1990)

4. M. Kawabe and T. Mano. Primates, 13, 213-228, (1972)

5. I. Matsuda, A. Tuuga, H. Bernard, and T. Fururich. Primates, 53, 13-23, (2012)

6. I. Matsuda, M. Tadahiro, C. Marcus, Y. Tomomi, T. Augustine, B. Henry, and H. Seigo. Biol. Lett., 7, 786789, (2011)

7. M Padmanaba, S. Douglas, B. Imam, and L. Nining. Environmental Management, 52, 348-359, (2013)

8. E.L. Benneth and F. Gombek, Natural History Publication, (1993)

9. D. Su and N. Jablonski. Folia Primantol, 80, 189-219, (2009)

10. J.G. Fleagle and D.J. Meldrum. American Journal of Primatology, 16, 227-249, (1988)

11. R.E Schultz. Essav Reviews. Educational, (1969)

12. E.H. Ashton and C.E. Oxnard. Proceedings of The Zoological Society of London, 142, 1-28, (2009)

13. J.E. Turnquist, N.D. Minugh-Purvis, N., Nonhuman. Primates in Biomedical Research, p.87-129, (2012)

14. N.G. Jablonski and F.S. Denise. Folia Primatol, 80, 189219, (2009) 